\title{
Article \\ Occurrence of Antibiotic Resistance Genes in Hermetia illucens Larvae Fed Coffee Silverskin Enriched with Schizochytrium limacinum or Isochrysis galbana Microalgae
}

\author{
Vesna Milanović ${ }^{1}$ (), Andrea Roncolini ${ }^{1}$, Federica Cardinali ${ }^{1}$, Cristiana Garofalo ${ }^{1}$, Lucia Aquilanti ${ }^{1}$, Paola Riolo ${ }^{1}$, \\ Sara Ruschioni ${ }^{1}$, Lorenzo Corsi ${ }^{1}$, Nunzio Isidoro ${ }^{1}$, Matteo Zarantoniello ${ }^{2}$, Ike Olivotto ${ }^{2}$, Simone Ceccobelli ${ }^{1}{ }^{10}$, \\ Stefano Tavoletti ${ }^{1}$, Francesca Clementi ${ }^{1}$ and Andrea Osimani ${ }^{1, *(D)}$ \\ 1 Department of Agricultural, Food and Environmental Sciences, Polytechnic University of Marche, \\ via Brecce Bianche, 60131 Ancona, Italy; v.milanovic@staff.univpm.it (V.M.); a.roncolini@pm.univpm.it (A.R.); \\ f.cardinali@staff.univpm.it (F.C.); c.garofalo@staff.univpm.it (C.G.); 1.aquilanti@staff.univpm.it (L.A.); \\ p.riolo@staff.univpm.it (P.R.); s.ruschioni@staff.univpm.it (S.R.); lorenzo.corsi1993@gmail.com (L.C.); \\ n.isidoro@staff.univpm.it (N.I.); s.ceccobelli@staff.univpm.it (S.C.); s.tavoletti@staff.univpm.it (S.T.); \\ f.clementi@staff.univpm.it (F.C.) \\ 2 Department of Life and Environmental Sciences, Polytechnic University of Marche, via Brecce Bianche, \\ 60131 Ancona, Italy; m.zarantoniello@pm.univpm.it (M.Z.); i.olivotto@staff.univpm.it (I.O.) \\ * Correspondence: a.osimani@univpm.it
}

\section{check for}

updates

Citation: Milanović, V.; Roncolini, A.; Cardinali, F.; Garofalo, C.; Aquilanti, L.; Riolo, P.; Ruschioni, S.; Corsi, L.; Isidoro, N.; Zarantoniello, M.; et al. Occurrence of Antibiotic Resistance Genes in Hermetia illucens Larvae Fed Coffee Silverskin Enriched with Schizochytrium limacinum or Isochrysis galbana Microalgae. Genes 2021, 12, 213. https://doi.org/10.3390/ genes12020213

Academic Editor: Michael Calcutt Received: 30 December 2020

Accepted: 29 January 2021

Published: 1 February 202

Publisher's Note: MDPI stays neutra with regard to jurisdictional claims in published maps and institutional affiliations.

Copyright: (C) 2021 by the authors. Licensee MDPI, Basel, Switzerland. This article is an open access article distributed under the terms and conditions of the Creative Commons Attribution (CC BY) license (https:// creativecommons.org/licenses/by/ $4.0 /)$
Abstract: Hermetia illucens larvae are among the most promising insects for use as food or feed ingredients due to their ability to convert organic waste into biomass with high-quality proteins. In this novel food or feed source, the absence of antibiotic-resistant bacteria and their antibiotic resistance (AR) genes, which could be horizontally transferred to animal or human pathogens through the food chain, must be guaranteed. This study was conducted to enhance the extremely scarce knowledge on the occurrence of AR genes conferring resistance to the main classes of antibiotics in a rearing chain of $H$. illucens larvae and how they were affected by rearing substrates based on coffee silverskin supplemented with increasing percentages of Schizochytrium limacinum or Isochrysis galbana microalgae. Overall, the PCR and nested PCR assays showed a high prevalence of tetracycline resistance genes. No significant effect of rearing substrates on the distribution of the AR genes in the H. illucens larvae was observed. In contrast, the frass samples were characterized by a significant accumulation of AR genes, and this phenomenon was particularly evident for the samples collected after rearing $H$. illucens larvae on substrates supplemented with high percentages $(>20 \%)$ of I. galbana. The latter finding indicates potential safety concerns in reusing frass in agriculture.

Keywords: Hermetia illucens; antibiotic resistance genes; rearing substrates; microalgae; coffee silverskin; frass

\section{Introduction}

The global population is estimated to reach 9 billion by 2050; hence, increasing amounts of animal feed and human food will be necessary to meet the demand of the growing population [1]. It is noteworthy that the production of animal feed is increasing the pressure on the environment by competing for water, land, and energy resources with human food production, both generating significant quantities of byproducts [1]. In such a context, edible insects can be used for the conversion of organic byproducts into valuable insect biomass rich in protein and fat that can be further used for human and animal nutrition [2,3]. Moreover, the production of insects is characterized by a low environmental impact in terms of feed conversion efficiency, a limited need for water and land sources and low $\mathrm{CO}_{2}$ and greenhouse gas emissions [4]. These characteristics are particularly important for aquaculture, where scarce and expensive fishmeal needs to be replaced with alternative high-protein feed to respond to the increasing world demand for fish $[4,5]$. 
In the European Union (EU), insect proteins from black soldier flies (Hermetia illucens), common houseflies (Musca domestica), lesser mealworms (Alphitobius diaperinus), yellow mealworms (Tenebrio molitor), banded crickets (Gryllodes sigillatus), field crickets (Gryllus assimilis), and house crickets (Acheta domesticus) have been authorized for use in aquaculture by the European Commission Regulation (EU) 2017/893 since mid-2017 [6]. Among these, $H$. illucens larvae are among the most promising insects to be used as feed, principally due to their good capability of converting a wide variety of organic wastes, such as coffee, vegetables, fruit, fish, urban organic wastes, and animal manure into the organic matter of the larval body, which is mainly composed of valuable proteins (approximately $55 \%$ of body dry weight (BDW)) and lipids (approximately 35\% BDW) [7]. The nutritional quality of H. illucens biomass is strongly influenced by the diet [8]. Despite high lipid content of the larvae, their fatty acid composition is characterized by low amounts of polyunsaturated (PUFA) and monounsaturated (MUFA) fatty acids. In this regard, Truzzi et al. [9] demonstrated that the substrates enriched with marine microalgae such as Schizochytrium sp. or Isochrysis sp. can significantly increase the relative quantity of lipids and proteins in $H$. illucens larvae, thus improving their nutritional value. Moreover, $H$. illucens has been reported to be able to degrade mycotoxins, pesticides, and tetracyclines as well as to remove heavy metals from contaminated wastes [10,11].

Living organisms including insects are natural carriers of microorganisms. The speciesspecific microbiota of insects may be altered by different extrinsic factors, such as diet, rearing conditions, handling, and processing [12]. Bacteria linked to edible insects could also be a reservoir of antibiotic resistance (AR) genes conferring resistance to antibiotics commonly used in human and veterinary medicine, agriculture, and aquaculture, whose extensive use has triggered selective pressure leading to the development of antibioticresistant strains [12]. Different public health organizations, such as the World Health Organization (WHO), the European Food Safety Authority (EFSA), the European Center for Disease Prevention and Control (ECDC) and the European Medicines Agency (EMA), have identified antibiotic resistance as a global threat to public health, giving special attention to the spread of AR genes via horizontal gene transfer among bacteria from the same or different species [13].

Previous studies were mainly focused on the presence of AR genes in small cricket powder, locusts, black ants, giant water bugs, rhino beetles, termite alates, silkworm pupae, mole crickets and black scorpions [14]; grasshoppers [15,16]; mealworms [14,15,17,18]; and small crickets $[14,18,19]$, all reporting a high prevalence of genes conferring resistance to tetracyclines and erythromycin. The possible contribution of feed to the occurrence of AR genes in edible insects as well as their vertical transmission via insect egg smearing has already been reported by Osimani et al. [20]. To the best of the author's knowledge, very few studies have been conducted on the occurrence of AR genes in H. illucens larvae $[10,21]$ and even fewer have been conducted on the effect of rearing substrate on the distribution of AR genes in the larvae as well as their possible accumulation in the frass (a mixture of insect excrements and substrate residues) [22]. It is noteworthy that two conversion cycles are needed when insects are used as food or feed, specifically, the conversion of organic products into insect biomass and then from insects to animals or humans [23]; hence, constant monitoring of the possible sources of AR genes to plan interventions aimed at reducing the spread of AR genes among feed and food chains should be a priority [13].

Given the above premises, the present study was designed to elucidate the possible effect of rearing substrates on the occurrence of selected AR genes in H. illucens larvae as well as on their accumulation or even depletion in frass. In the concept of circular economy, the H. illucens larvae were reared on a basal substrate constituted by coffee roasting byproducts (coffee silverskin, Cs) supplemented with increasing percentages of microalgae (Schizochytrium limacinum or Isochrysis galbana) as the source of PUFAs such as docosahexaenoic, stearidonic, and $\alpha$-linolenic acid $[9,24]$. On the other hand, Cs, rich in polyphenols and mainly composed of dietary fibers $(\approx 55 \%)$, proteins $(\approx 19 \%)$, 
carbohydrates $(\approx 6 \%)$, and fat $(\approx 2 \%)$, has been reported to have prebiotic and antioxidant activities [25].

The DNA extracted from the rearing substrates, larvae and frass samples was screened for the presence of $12 \mathrm{AR}$ genes conferring resistance to five key classes of antibiotics commonly used in human and veterinary medicine as well as in agriculture and aquaculture, such as erythromycin $(\operatorname{erm}(\mathrm{A}), \operatorname{erm}(\mathrm{B}), \operatorname{erm}(\mathrm{C}))$, vancomycin $(\operatorname{van} A, \operatorname{van} B)$, tetracycline $[\operatorname{tet}(\mathrm{K})$, tet $(\mathrm{M})$, tet $(\mathrm{O})$, tet $(\mathrm{S})], \beta$-lactams (blaZ, mec $A)$, and aminoglycosides $\left(\right.$ aac $\left(6^{\prime}\right)-l e$ aph $\left(2^{\prime \prime}\right)-l a$, referred to as aac-aph). The target AR genes were selected from among those frequently found in bacteria isolated from various animal- and plant-based foods [26,27] showing a high probability to be horizontally transferred into human pathogens [28].The results obtained were subjected to statistical analysis, including cluster analysis and principal coordinates analysis (PCoA).

\section{Materials and Methods}

\subsection{Preparation of H. Illucens Rearing Substrates}

Nine different substrates were prepared for the rearing of $H$. illucens larvae. Cs obtained from a mixture of Robusta and Arabica varieties of roasting coffee (Saccaria caffè S.R.L., Marina di Montemarciano, AN, Italy) was used as a basal rearing substrate (control). The Cs was frozen at $-20^{\circ} \mathrm{C}$ and then ground to a $2 \pm 0.4 \mathrm{~mm}$ particle size before the preparation of rearing substrates as detailed by Truzzi et al. [9,24]. The experimental substrates were prepared by including increasing percentages $(5 \%, 10 \%, 20 \%$, and $25 \%$ ) of freeze-dried S. limacinum (S) or I. galbana (I) microalgae in the basal Cs substrate. The organically produced microalgae were provided by AlghItaly Società Agricola S.R.L. (Sommacampagna (VR), Italy). No antibiotics were used for the production of microalgae. An aliquot of each of the rearing substrates was stored at $-20{ }^{\circ} \mathrm{C}$ until further analysis.

\subsection{Rearing of H. Illucens Larvae}

Six-day-old larvae of H. illucens purchased from Smart Bugs s.s. (Ponzano Veneto, TV, Italy) were reared on 9 different substrates at the experimental facility of the Department of Agricultural, Food and Environmental Sciences (Polytechnic University of Marche, Ancona, Italy). The $H$. illucens were divided into 9 groups, each containing 750 larvae, and then further divided into 5 replicates, each containing 150 larvae. The feeding rate within the plastic boxes was $100 \mathrm{mg}$ day $^{-1}$ until the prepupae stage was reached (after approximately 1 month). The larvae were transferred to new substrates once a week during the rearing period. No antibiotics were used for the commercial and experimental rearing of $H$. illucens larvae. The details of the rearing conditions are as reported by Truzzi et al. $[9,24]$. At the end of the experiment, larvae, and frass from each of five replicates per substrate type were collected manually under sterile conditions, pooled together to reduce the effect of biological variation, and stored at $-20{ }^{\circ} \mathrm{C}$ until analysis.

\subsection{DNA Extraction}

The rearing substrates, $H$. illucens larvae and their frass (10 g each) were added to $90 \mathrm{~mL}$ of sterile physiological solution $\left(0.85 \% \mathrm{NaCl}, w v^{-1}\right)$ and homogenized in a Stomacher machine (400 Circulator, International PBI, Milan, Italy) for 5 min at $260 \mathrm{rpm}$. Aliquots $\left(1.5 \mathrm{~mL}\right.$ ) of the obtained homogenates (dilution $10^{-1}$ ) were centrifuged for $10 \mathrm{~min}$ at 14,000 rpm to collect the cell pellets, which were further used for DNA extraction using an E.Z.N.A. soil DNA extraction kit (Omega Biotek, Norcross, GA, USA). The quantity and purity of the extracted DNAs were determined by a Nanodrop ND 1000 (Thermo Fisher Scientific, Wilmington, DE, USA) and standardized to a concentration of $25 \mathrm{ng} \mu \mathrm{L}^{-1}$ before further analysis. Moreover, the effective extraction of the bacterial DNA was checked by PCR amplification of the bacterial $16 \mathrm{~S}$ rRNA gene using the universal prokaryotic primer pair 27F-1495R [29]. 


\subsection{Detection of AR Genes by PCR and Nested PCR}

The extracted DNAs were screened by PCR for the detection of 12 AR genes conferring resistance to erythromycin $[\operatorname{erm}(\mathrm{A}), \operatorname{erm}(\mathrm{B}), \operatorname{erm}(\mathrm{C})]$, tetracycline $[\operatorname{tet}(\mathrm{K}), \operatorname{tet}(\mathrm{M}), \operatorname{tet}(\mathrm{O}), \operatorname{tet}(\mathrm{S})]$, vancomycin (vanA, vanB), $\beta$-lactams (blaZ, mec $A$ ) and aminoglycosides (aac-aph). To increase the detection sensitivity, the negative PCR amplification products for each AR gene in the study were further subjected to a nested PCR assay. The primers used for the PCR and nested PCR as well as the thermal cycling conditions for all but the aac-aph gene were as previously reported by Milanović et al. [30], while the PCR conditions for the latter gene were detailed by Garofalo et al. [31]. DNA was extracted from 12 bacterial reference strains $[16,17,19,20]$, each carrying one of the AR genes under study, and they were used as positive controls in each PCR and nested PCR assay, whereas the DNA extracted from Enterococcus faecalis JH2-2 [32] was used as a negative control. Furthermore, a blank control containing molecular biology grade water instead of DNA was used in each assay to exclude the presence of PCR contaminants. The presence/absence of AR genes in the samples was checked by analyzing the PCR and nested PCR amplification products by electrophoresis on a $1.5 \%(w / v)$ agarose gel. The correct size of the amplification products for each AR gene in the study was determined by comparison with a $100 \mathrm{bp}$ DNA molecular weight marker (HyperLadder ${ }^{\mathrm{TM}} 100 \mathrm{bp}$, Bioline, London, UK) as shown in Supplementary Figure S1. To check the specificity of PCR/nested PCR assay, the randomly selected amplification products for each AR gene in study were sent to Genewiz (Leipzig, Germany) for the purification and sequencing. The obtained sequences were subjected to Basic Local Alignment Search Tool (BLAST) analysis available from National Center for Biotechnology Information showing high similarity ( $\geq 98 \%)$ with the corresponding sequences deposited in GenBank database, thus confirming the specificity of the PCR/ nested PCR primers used in study.

\subsection{Statistical Analysis}

The detection frequency of AR genes in each sample was calculated as the total number of detected AR genes divided by the total number of tested AR genes. Similarly, the detection frequency for each AR gene in the study among the samples was calculated as the total number of positive samples divided by the number of samples.

A data matrix was created with PCR- and nested PCR-positive and PCR-negative samples scored as 1 or 0 , respectively. A Jaccard similarity index matrix was adopted for hierarchical cluster analysis by applying the unweighted pair group method with the arithmetic mean (UPGMA). PCoA was carried out using NTSYS software (Applied Biostatistics Inc., New York, NY, USA). The combination of principal coordinates allowing the best separation of the groups found by cluster analysis was identified through the bidimensional graphical representations of the PCoA scores of all samples. Following the results of the cluster analysis and PCoA, the difference in AR gene frequencies (presence vs. absence) between the categories of samples was evaluated by Pearson's chi square test $\left(\chi^{2}\right)$ (JMP statistical software version 11.0.0, SAS Inst. Inc., Cary, NC, USA). Comparisons among groups included an overall $\chi^{2}$ test followed by orthogonal contrasts.

\section{Results}

The results of the PCR and nested PCR screening of $12 \mathrm{AR}$ genes conferring resistance to erythromycin, tetracycline, vancomycin, $\beta$-lactams, and aminoglycosides in nine experimental rearing substrates as well as in the H. illucens larvae and the resulting frass are reported in Table 1. The screening was first performed by PCR and, in the case of negative results, by a nested PCR assay. Generally, the genes conferring resistance to tetracyclines, namely, tet $(\mathrm{S})$, tet $(\mathrm{M})$ and $\operatorname{tet}(\mathrm{K})$, were detected with the highest frequencies, at $92.6 \%$, $88.9 \%$, and $63.0 \%$ of the samples, respectively, followed by the erythromycin resistance gene $\operatorname{erm}(\mathrm{B})$, detected in $59.3 \%$ of the samples. In contrast, the blaZ and vanB genes were never identified. Nested PCR allowed the detection of most of the analyzed AR genes with 
the $\operatorname{erm}(\mathrm{A}), m e c A$, and aac-aph genes detected exclusively by this method. Generally, the frass samples were characterized by the largest number of different AR genes.

Table 1. Antibiotic resistance (AR) genes detected by PCR and nested PCR.

\begin{tabular}{|c|c|c|c|c|c|c|c|c|c|c|c|c|c|}
\hline \multirow{2}{*}{ Sample } & \multicolumn{12}{|c|}{ AR Genes } & \multirow{2}{*}{$\begin{array}{l}\% \text { of Positivity } \\
\text { for AR Genes }\end{array}$} \\
\hline & $\operatorname{erm}(\mathrm{A})$ & erm(B) & erm $(\mathrm{C})$ & $\operatorname{van} A$ & $\operatorname{van} B$ & tet(M) & $\operatorname{tet}(\mathrm{O})$ & $\operatorname{tet}(\mathrm{S})$ & $\operatorname{tet}(\mathrm{K})$ & mecA & blaZ & $a a c-a p h$ & \\
\hline Cs & - & - & - & - & - & $\mathbf{\square}$ & - & $\mathbf{\square}$ & $\mathbf{\square}$ & - & - & - & 25.0 \\
\hline CsS5 & - & - & - & - & - & $\mathbf{\square}$ & - & $\mathbf{\square}$ & - & - & - & - & 16.7 \\
\hline CsS10 & - & $\boldsymbol{\square}$ & - & - & - & $\boldsymbol{\square}$ & - & $\square$ & - & - & - & $\mathbf{\square}$ & 33.3 \\
\hline CsS20 & - & - & - & - & - & $\mathbf{\square}$ & - & $\mathbf{\square}$ & - & - & - & - & 16.7 \\
\hline CsS25 & - & - & - & - & - & $\boldsymbol{\square}$ & - & $\square$ & $\square$ & - & - & - & 25.0 \\
\hline CsI5 & $\mathbf{\square}$ & - & - & - & - & $\mathbf{\square}$ & - & $\mathbf{\square}$ & $\mathbf{\square}$ & - & - & - & 33.3 \\
\hline CsI10 & - & - & - & - & - & $\mathbf{\square}$ & - & $\square$ & $\mathbf{\square}$ & - & - & $\mathbf{\square}$ & 33.3 \\
\hline CsI20 & - & $\mathbf{\square}$ & - & - & - & $\boldsymbol{\square}$ & - & $\mathbf{\square}$ & $\mathbf{\square}$ & $\mathbf{\square}$ & - & - & 41.6 \\
\hline CsI25 & - & $\mathbf{\square}$ & - & - & - & $\boldsymbol{\square}$ & $\boldsymbol{\square}$ & $\boldsymbol{\square}$ & $\mathbf{\square}$ & - & - & - & 41.6 \\
\hline $\begin{array}{c}\% \text { of } \\
\text { positive } \\
\text { substrate } \\
\text { samples } \\
\text { for each }\end{array}$ & 11.1 & 33.3 & 0.0 & 0.0 & 0.0 & 100 & 11.1 & 100 & 66.7 & 11.1 & 0.0 & 22.2 & \\
\hline AR gene & & & & & & & & & & & & & \\
\hline HCs & - & $\mathbf{\square}$ & - & - & - & - & $\boldsymbol{\square}$ & - & - & - & - & - & 16.7 \\
\hline HCsS5 & - & - & - & - & - & $\square$ & $\mathbf{0}$ & $\mathbf{\square}$ & $\mathbf{\square}$ & - & - & - & 33.3 \\
\hline HCsS10 & - & $\mathbf{\square}$ & - & - & - & $\mathbf{\square}$ & $\boldsymbol{\square}$ & $\mathbf{\square}$ & $\mathbf{\square}$ & - & - & - & 41.6 \\
\hline HCsS20 & - & - & $\mathbf{\square}$ & - & - & - & - & 口 & - & - & - & - & 16.7 \\
\hline HCsS25 & - & - & - & - & - & - & - & - & $\mathbf{\square}$ & - & - & - & 8.33 \\
\hline HCsI5 & - & $\boldsymbol{\square}$ & $\boldsymbol{\square}$ & - & - & $\boldsymbol{\square}$ & - & $\square$ & - & - & - & - & 33.3 \\
\hline HCsI10 & - & - & - & - & - & $\mathbf{\square}$ & $\mathbf{\square}$ & $\mathbf{\square}$ & - & - & - & - & 25.0 \\
\hline HCsI20 & - & $\square$ & - & - & - & $\square$ & - & $\mathbf{\square}$ & - & - & - & $\square$ & 33.3 \\
\hline $\begin{array}{c}\text { HCsI25 } \\
\% \text { of } \\
\text { positive }\end{array}$ & $\boldsymbol{\square}$ & $\boldsymbol{\square}$ & - & - & - & $\square$ & $\mathbf{\square}$ & $\mathbf{\square}$ & - & - & - & 口 & 50.0 \\
\hline $\begin{array}{c}\text { H. illucens } \\
\text { samples } \\
\text { for each } \\
\text { AR gene }\end{array}$ & 11.1 & 55.6 & 22.2 & 0.0 & 0.0 & 66.7 & 55.6 & 77.8 & 33.3 & 0.0 & 0.0 & 22.2 & \\
\hline FCs & $\boldsymbol{\square}$ & - & - & - & - & $\square$ & $\boldsymbol{\square}$ & $\square$ & $\square$ & - & - & - & 41.6 \\
\hline FCsS5 & $\mathbf{\square}$ & $\mathbf{\square}$ & - & - & - & $\square$ & $\mathbf{a}$ & $\square$ & $\mathbf{\square}$ & - & - & $\mathbf{\square}$ & 58.3 \\
\hline FCsS10 & $\mathbf{\square}$ & $\square$ & - & - & - & $\square$ & $\mathbf{\square}$ & $\square$ & $\mathbf{\square}$ & - & - & $\mathbf{\square}$ & 58.3 \\
\hline FCsS20 & $\mathbf{\square}$ & $\mathbf{\square}$ & $\square$ & - & - & $\square$ & $\mathbf{\square}$ & $\square$ & $\mathbf{\square}$ & - & - & $\mathbf{\square}$ & 66.6 \\
\hline FCsS25 & 口 & $\square$ & - & - & - & $\square$ & - & $\square$ & - & - & - & $\mathbf{0}$ & 41.6 \\
\hline FCsI5 & $\mathbf{\square}$ & $\square$ & $\square$ & $\square$ & - & $\square$ & $\mathbf{\square}$ & $\square$ & $\mathbf{\square}$ & $\mathbf{\square}$ & - & $\mathbf{\square}$ & 83.3 \\
\hline FCsI10 & $\mathbf{a}$ & $\square$ & $\square$ & $\square$ & - & $\square$ & a & $\square$ & $\square$ & $\square$ & - & 口 & 83.3 \\
\hline FCsI20 & $\mathbf{\square}$ & $\square$ & $\square$ & - & - & $\square$ & $\mathbf{a}$ & $\square$ & $\square$ & $\mathbf{\square}$ & - & $\mathbf{a}$ & 75.0 \\
\hline $\begin{array}{c}\text { FCsI25 } \\
\% \text { of } \\
\text { positive }\end{array}$ & $\mathbf{\square}$ & $\square$ & $\square$ & - & - & $\square$ & $\mathbf{\square}$ & $\square$ & $\square$ & $\mathbf{\square}$ & - & $\mathbf{0}$ & 75.0 \\
\hline $\begin{array}{c}\text { frass } \\
\text { samples } \\
\text { for each } \\
\text { AR gene }\end{array}$ & 100 & 88.9 & 55.6 & 22.2 & 0.0 & 100 & 88.9 & 100 & 88.9 & 44.4 & 0.0 & 22.2 & \\
\hline $\begin{array}{l}\text { Overall \% } \\
\text { of } \\
\text { positive } \\
\text { samples } \\
\text { for each } \\
\text { AR gene }\end{array}$ & 40.7 & 59.3 & 25.9 & 7.4 & 0.0 & 88.9 & 51.9 & 92.6 & 63.0 & 18.5 & 0.0 & 44.4 & \\
\hline
\end{tabular}

$\square$, sample positive after PCR; $\mathbf{\square}$, sample positive after PCR and nested PCR; -, negative sample; Cs, rearing substrate composed of $100 \%$ coffee silverskin; CsS5, CsS10, CsS20, CsS25 and CsI5, CsI10, CsI20, CsI25, rearing substrates supplemented with 5\%, 10\%, 20\%, and 25\% Schizochytrium limacinum and Isochrysis galbana, respectively; HCsS5, HCsS10, HCsS20, HCsS25 and HCsI5, HCsI10, HCsI20, HCsI25, Hermetia illucens larvae reared on the corresponding substrates; FCsS5, FCsS10, FCsS20, FCsS25 and FCsI5, FCsI10, FCsI20, FCsI25, frass collected from the H. illucens larvae reared on the corresponding substrates. Color-coding: feeding substrates (blue), H. illucens larvae (black), and frass (red). 
Considering rearing substrates, the tet $(\mathrm{M})$ and tet $(\mathrm{S})$ genes were widely present in all analyzed substrates, with the tet $(\mathrm{K})$ gene found in Cs as well as in substrates containing I. galbana and in substrate CsS25 prepared by the highest inclusion level of S. limacinum $(25 \%)$. Regarding erythromycin resistance genes, $\operatorname{erm}(\mathrm{B})$ was detected sporadically among different substrates. The aac-aph gene was detected only in the substrates containing $10 \%$ of both microalgae (CsS10 and CsI10). Finally, a larger number of AR genes was detected in substrates prepared with I. galbana than in those containing S. limacinum, irrespective of the inclusion percentages.

Regarding $H$. illucens larvae reared on experimental substrates, no positive results were obtained after the first round of PCR for the larvae grown on substrates containing $S$. limacinum, while the larvae HCsI20 and HCsI25 reared on substrates containing I. galbana were positive for the $\operatorname{erm}(\mathrm{B})$ and tet $(\mathrm{M})$ genes after the first PCR. Moreover, the absence of $\operatorname{erm}(\mathrm{A})$ and $a a c-a p h$ as well as the tet(K) gene was observed in the larvae reared on substrates prepared with S. limacinum and I. galbana, respectively. The genes detected with the highest frequencies were tet $(\mathrm{S})$, tet $(\mathrm{M})$, tet $(\mathrm{O})$, and $\operatorname{erm}(\mathrm{B})$, whereas the $\operatorname{erm}(\mathrm{A})$ and aac-aph genes were found only in $\mathrm{H}$. illucens larvae reared on substrates containing high percentages $(>20 \%)$ of I. galbana. The highest number $(50 \%)$ of AR genes was detected in H. illucens larvae grown on the substrate containing $25 \%$ I. galbana (HCsI25).

In contrast to the samples of rearing substrates and $H$. illucens larvae, where the AR genes were mostly detected by nested PCR, most of the frass samples were positive even after the first round of the PCR assay for the $\operatorname{erm}(\mathrm{B}), \operatorname{erm}(\mathrm{C}), \operatorname{tet}(\mathrm{M})$, and $\operatorname{tet}(\mathrm{S})$ genes. The $m e c A$ and $\operatorname{erm}(\mathrm{C})$ genes were found exclusively in frass samples collected after the rearing of larvae on substrates supplemented with I. galbana, except for FCsS20, which also resulted in positivity for the $\mathrm{erm}(\mathrm{C})$ gene.

Cluster analysis (Figure 1) identified two main clusters and four samples of H. illucens larvae that showed a low similarity with the two clusters and among each other. The results of the cluster analysis are discussed based on the grouping of three main categories of samples that were investigated for the occurrence of AR genes, namely, feeding substrates, larvae and frass.

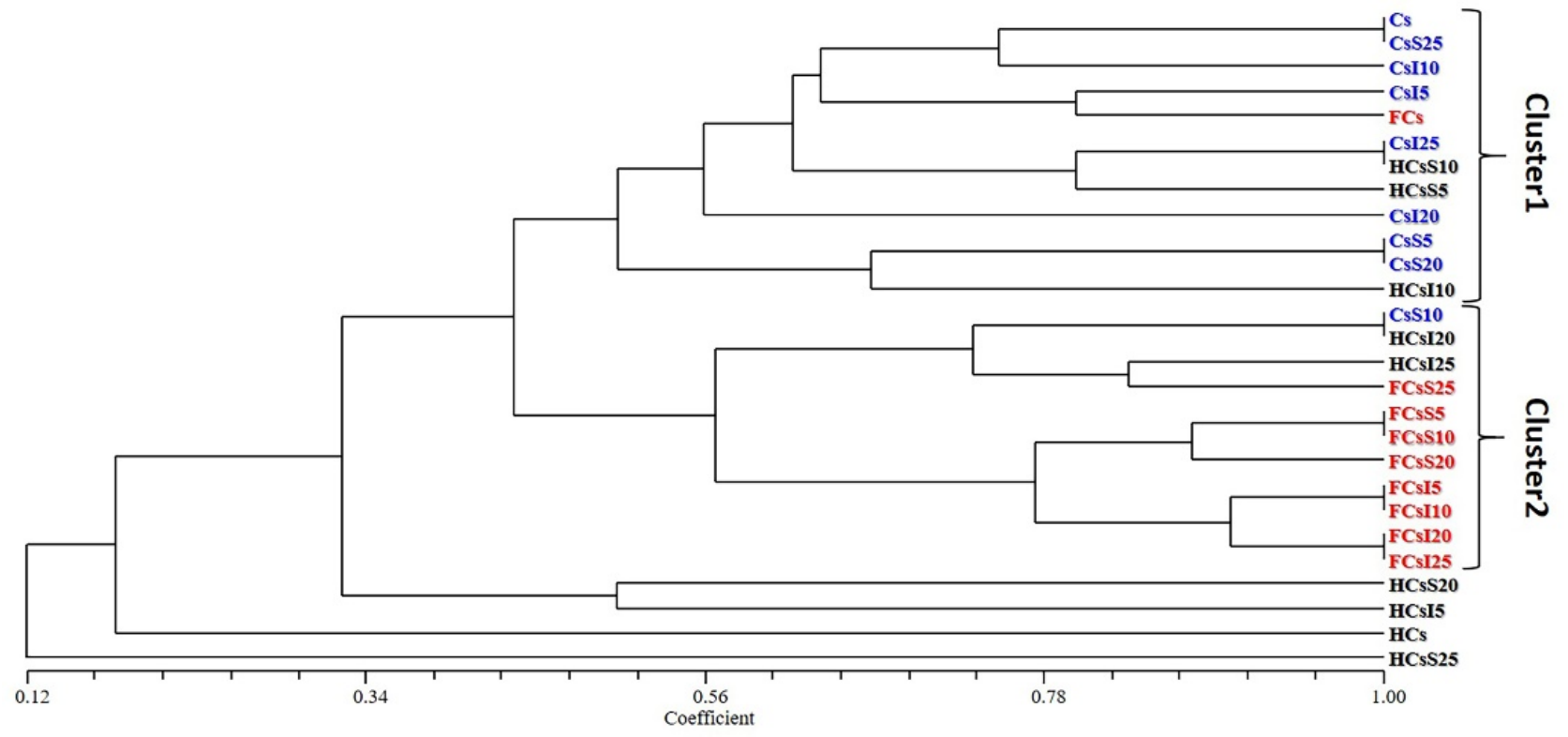

Figure 1. Hierarchical clustering dendrogram plotted from the cluster analysis. Cs, rearing substrate composed of $100 \%$ coffee silverskin; CsS5, CsS10, CsS20, CsS25 and CsI5, CsI10, CsI20, CsI25, rearing substrates supplemented with 5\%, 10\%, 20\%, and 25\% Schizochytrium limacinum and Isochrysis galbana, respectively; HCsS5, HCsS10, HCsS20, HCsS25 and HCsI5, HCsI10, HCsI20, HCsI25, Hermetia illucens larvae reared on the corresponding substrates; FCsS5, FCsS10, FCsS20, FCsS25 and FCsI5, FCsI10, FCsI20, FCsI25, frass collected from the H. illucens larvae reared on the corresponding substrates. Color-coding: feeding substrates (blue), H. illucens larvae (black), and frass (red). 
The majority of the substrate samples were grouped in Cluster 1, with the exception of CsS10 being grouped in Cluster 2. All frass samples inoculated with both S. limacinum and I. galbana (FCsI and FCsS) were included in Cluster 2, whereas the FC sample (control) was grouped in Cluster 1. Moreover, several frass samples in Cluster 2 shared the same AR gene profile (FCsS5 and FCsS10, FCsI5 and FCsI10, FCsI20, and FCsI25).

The larval samples were included in both clusters, with HCsS and HCsI mainly grouped in clusters 1 and 2, respectively, whereas HCsS25 was clearly different from the other analyzed samples. Therefore, the H. illucens samples were characterized by a higher variability in AR gene distribution than the feeding substrates and frass samples.

PCoA (Figures 2 and 3) confirmed the differentiation between Clusters 1 and 2. In particular, the first two principal coordinates explained $25.12 \%$ of the total variation and separated Cluster 1 from Cluster 2 (Figure 2). The third principal coordinate contributed to $8.86 \%$ of the total variance and moved the four isolated samples away from the two main clusters (Figure 3).

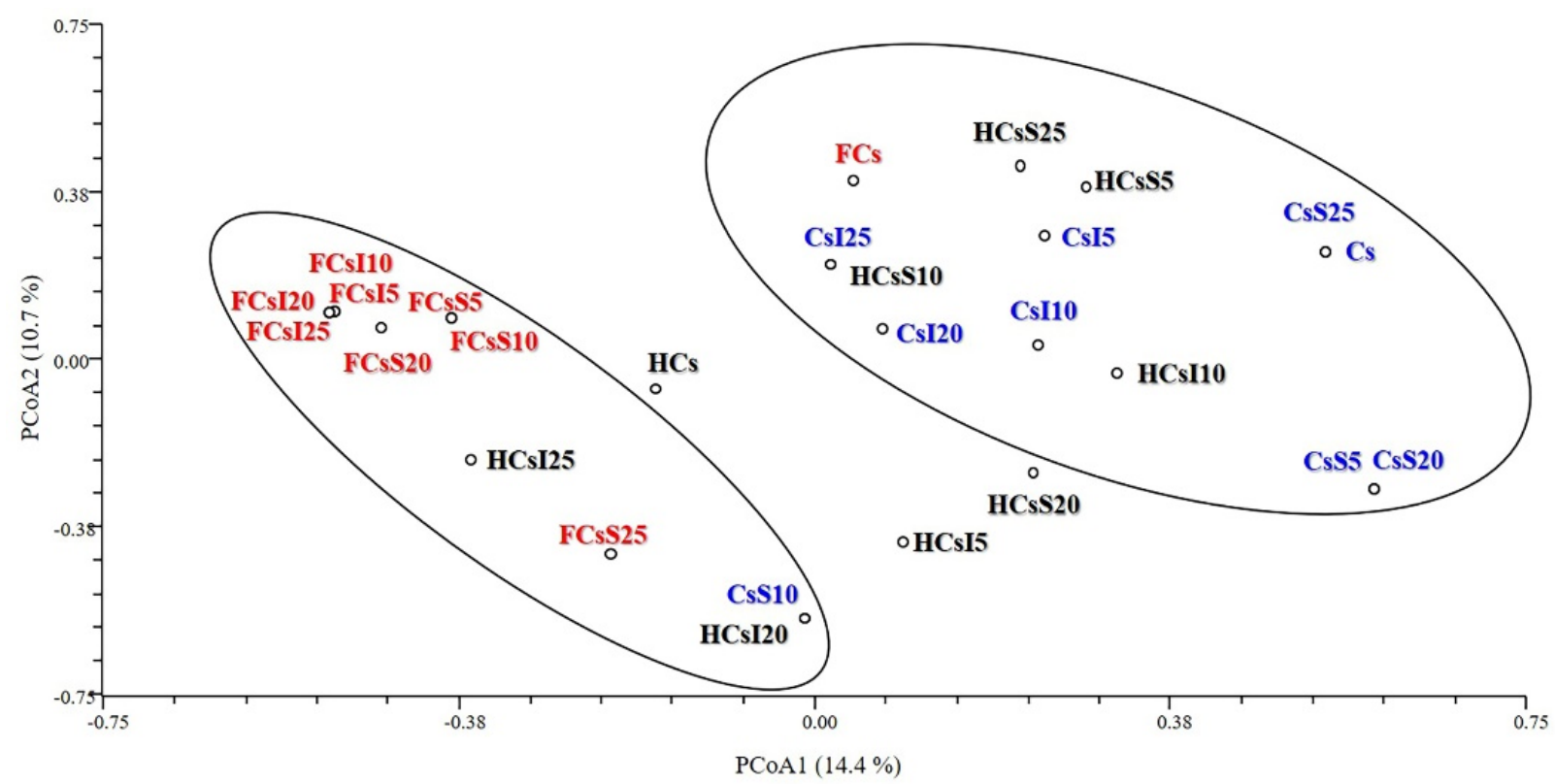

Figure 2. Principal coordinate analysis (PCoA) plot: principal coordinates 1 and 2. Cs, rearing substrate composed of 100\% coffee silverskin; CsS5, CsS10, CsS20, CsS25 and CsI5, CsI10, CsI20, CsI25, rearing substrates supplemented with 5\%, 10\%, 20\%, and 25\% Schizochytrium limacinum and Isochrysis galbana, respectively; HCsS5, HCsS10, HCsS20, HCsS25 and HCsI5, HCsI10, HCsI20, HCsI25, Hermetia illucens larvae reared on the corresponding substrates; FCsS5, FCsS10, FCsS20, FCsS25 and FCsI5, FCsI10, FCsI20, FCsI25, frass collected from the H. illucens larvae reared on the corresponding substrates. Color-coding: feeding substrates (blue), H. illucens larvae (black), and frass (red).

Due to the results of the cluster analysis and PCOA, the AR gene frequencies detected in the substrates, larvae, and frass were calculated and compared by the $\chi^{2}$ test. As shown in Table 2A, the absolute frequencies of the AR genes highlighted clear differences among the groups of samples, confirmed by the highly significant overall $\chi^{2}$ test (Table $2 \mathrm{~B}$ ). Orthogonal contrasts showed a significant difference between frass and the other two groups, as shown by the first contrast. No differences were found between the rearing substrates and the larval groups (contrast 2, Table 2B). In general, genes coding for resistance were prevalent in the frass samples $(65 \%)$ compared to the rearing substrate $(30 \%)$ and the larval (29\%) samples. 


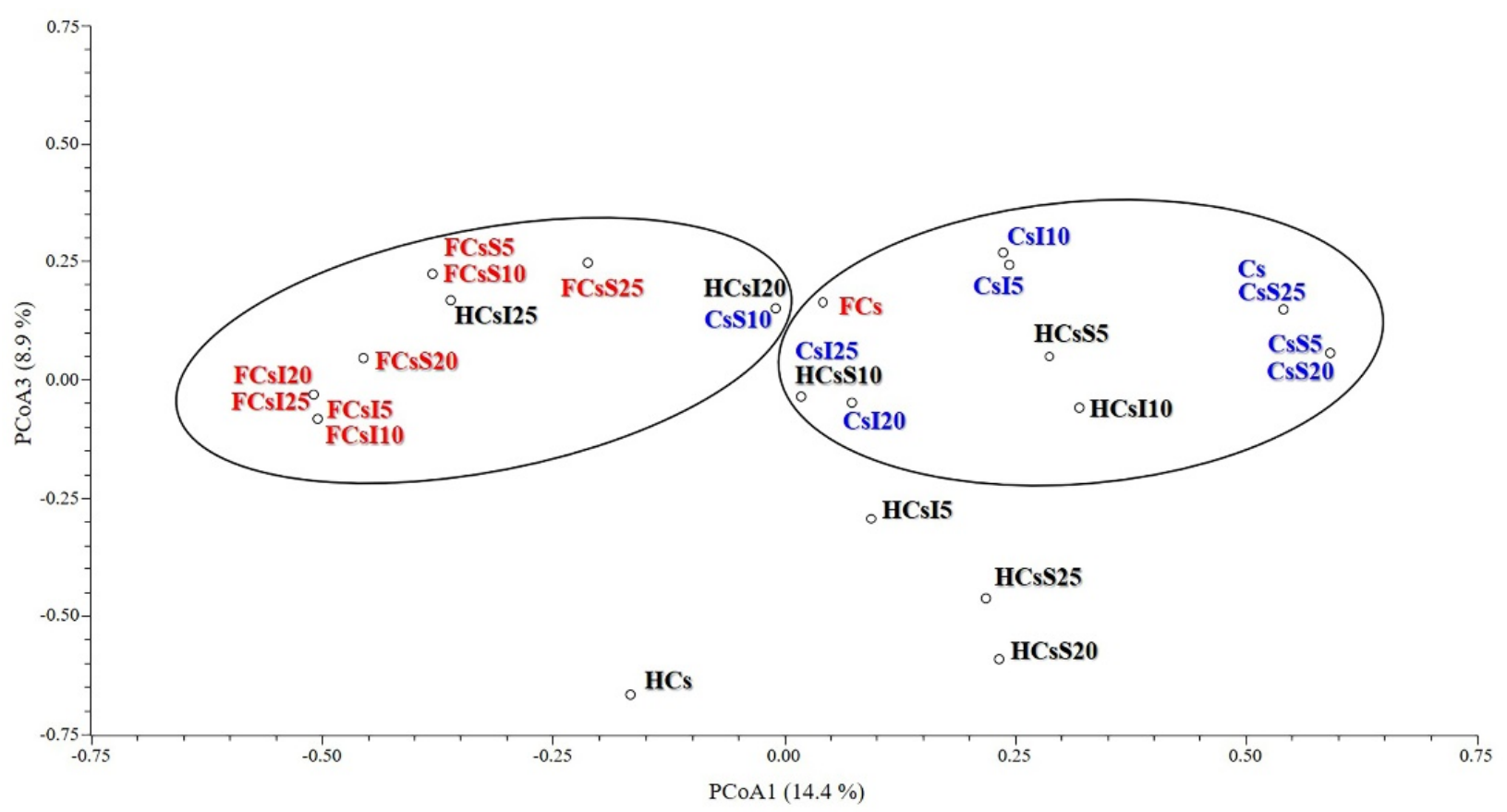

Figure 3. Principal coordinate analysis (PCoA) plot: principal coordinates 1 and 3. Cs, rearing substrate composed of 100\% coffee silverskin; CsS5, CsS10, CsS20, CsS25 and CsI5, CsI10, CsI20, CsI25, rearing substrates supplemented with 5\%, 10\%, 20\%, and 25\% Schizochytrium limacinum and Isochrysis galbana, respectively; HCsS5, HCsS10, HCsS20, HCsS25 and HCsI5, HCsI10, HCsI20, HCsI25, Hermetia illucens larvae reared on the corresponding substrates; FCsS5, FCsS10, FCsS20, FCsS25 and FCsI5, FCsI10, FCsI20, FCsI25, frass collected from the H. illucens larvae reared on the corresponding substrates. Color-coding: feeding substrates (blue), H. illucens larvae (black), and frass (red).

Table 2. Results of the chi-square $\left(\chi^{2}\right)$ test: (A) AR gene frequencies of each group and (B) total $\chi^{2}$ and orthogonal comparisons.

\begin{tabular}{|c|c|c|c|}
\hline \multicolumn{4}{|c|}{ (A) Antibiotic Resistance (AR) } \\
\hline Group & \multicolumn{2}{|c|}{ Presence* } & Absence * \\
\hline Feeding substrates (Cs) & \multicolumn{2}{|c|}{$32(30)$} & $76(70)$ \\
\hline Hermetia illucens larvae $(\mathrm{H})$ & \multicolumn{2}{|c|}{$31(29)$} & $77(71)$ \\
\hline Frass $(\mathrm{F})$ & \multicolumn{2}{|c|}{$70(65)$} & $38(35)$ \\
\hline \multicolumn{4}{|c|}{ (B) $\chi^{2}$ Test } \\
\hline Comparisons & $x^{2}$ & $p$-value & OR $(95 \%$ CI) \\
\hline Overall test (Cs vs. $\mathrm{H}$ vs. F) & 37.83 & $<0.0001$ & \\
\hline Comparisons & $x^{2}$ & $p$-value & OR $(95 \%$ CI) \\
\hline \multicolumn{4}{|l|}{ Orthogonal comparisons } \\
\hline 1. $(\mathrm{Cs}+\mathrm{H})$ vs. $\mathrm{F}$ & 37.81 & $<0.0001$ & $4.47(2.74-7.32)$ \\
\hline 2. Cs vs. $\mathrm{H}$ & 0.02 & n.s. & $0.96(0.53-1.72)$ \\
\hline
\end{tabular}

* the relative frequencies (\%) are reported in brackets. n.s., not significant; OR, odds ratio; CI, confidence interval.

\section{Discussion}

The DNAs extracted from the pooled samples of H. illucens larvae, their rearing substrates and corresponding frass samples were screened for the occurrence of $12 \mathrm{AR}$ genes using PCR assays. The samples that were negative for each of the AR genes under study were further subjected to nested PCR assays designed to enhance the gene detection sensitivity, as previously reported by Garofalo et al. [31]. The high sensitivity of the latter method was confirmed in recent studies aimed at detecting the same AR genes in different edible insects $[14,16,17,19,20]$ as well as in human stool and saliva samples $[30,33]$. 
In the present study, nested PCR allowed the detection of the higher number of the analyzed AR genes with respect to the first round PCR. The erm(A), mecA, and aac-aph genes were exclusively found by nested PCR, which could be related to a small number of their gene copies in the samples, not detectable by first round PCR.

The most prevalent genes among all tested samples were those conferring resistance to tetracyclines. This is not surprising since the amount of tetracyclines used worldwide exceeds almost every other class of antibiotics, mainly due to their extensive range of activity and low cost [34]. It is noteworthy that bacterial resistance to tetracyclines has increased in the last thirty years, with 46 different genes conferring resistance to this class of antibiotics identified among various Gram-positive and Gram-negative bacteria isolated from humans, animals, and the environment [35].

Of note, to guarantee the safety of food or feed, both the ingredients and the final products should be free from microbiological contaminants, including antibiotic-resistant bacteria [36]. Regarding edible insects, during rearing, bacteria in the insect feed come into direct contact with the bacteria from the insect's gut, thus making it possible for them to exchange AR genes [22]. In the present study, the tetracycline resistance genes tet $(\mathrm{M})$ and tet $(\mathrm{S})$, both encoding ribosomal protection proteins, largely prevailed among the rearing substrates. A high incidence of tet $(\mathrm{M})$ was expected since this gene has the widest host range among all tet genes, principally due to its association with mobile genetic elements, which increase its transferability among bacteria [35]. Similarly, the tet(S) gene, showing $79 \%$ amino identity with tet $(\mathrm{M})$, has been identified among Firmicutes and Gammaproteobacteria from a broad range of ecological sources [37]. The inclusion of $I$. galbana in the basal substrate (Cs), especially at high percentages (20 and 25\%), seems to be associated with a higher prevalence of the tested AR genes when compared with substrates supplemented with S. limacinum. Furthermore, some of the tested genes, such as mecA and tet $(\mathrm{O})$, while not found in Cs, emerged exclusively in substrates enriched with I. galbana, whereas the tet $(\mathrm{K})$ gene, previously detected in Cs, largely prevailed in mixed substrates containing the latter microalgae. This finding could be due to the beneficial effect of $I$. galbana on the proliferation of bacteria carrying these genes.

To the author's knowledge, no studies have been performed on the presence of antibiotic residues or on the occurrence of AR genes in coffee silverskin or microalgae-based substrates, whereas a similar study investigating the incidence of AR genes in organic wheatmeal used for the rearing of edible mealworms reported the exclusive presence of tetracycline tet $(\mathrm{S})$ and tet $(\mathrm{K})$ genes [20]. A very recent study focused on the microbial dynamics of the same rearing substrates analyzed in the present study reported the massive presence of lactic acid bacteria (LAB) belonging to the Lactobacillus, Leuconostoc, and Weissella genera [38]. In the study of Osimani et al. [38], the prevalence of Leuconostoc in the basal Cs substrate and substrates supplemented with S. limacinum was reported; moreover, the prevalence of Weissella in substrates supplemented with I. galbana was observed [38]. Although LAB have been recognized as safe with a QPS (qualified presumption of safety) status given by the EFSA [39], the frequent detection of LAB carrying AR genes that can be horizontally transferred to pathogens through the food chain is of great concern [40].

Despite the growing interest of the scientific community in $H$. illucens larvae for bioconversion and bioremediation, limited information is available on safety aspects regarding its gut microbiota [41]. Among the limited number of studies investigating the composition of the H. illucens gut microbiota, only a few have focused on the effect of diet on its composition and they have shown that the gut microbiota is strongly influenced by the diet, but a stable core microbiota is also present [38,41-43]. Another important safety aspect neglected in most of the studies performed on H. illucens larvae is the occurrence of antibiotic-resistant bacteria and their AR genes, which in turn could be transferred to fish or livestock destined for human consumption.

In the present study, H. illucens larvae reared on the basal Cs substrate resulted positive only for the $\operatorname{erm}(\mathrm{B})$ and $\operatorname{tet}(\mathrm{O})$ genes, which, together with the tet $(\mathrm{M})$ and tet $(\mathrm{S})$ genes, prevailed among $H$. illucens larvae irrespective of the microalgae used for the enrichment 
of the substrates. Recently, Cifuentes et al. [22] detected the tet(M) gene in both the larval and pupal gut of $H$. illucens reared on chicken feed. Another recent study on the microbial dynamics and the occurrence of AR genes in H. illucens larvae fed soy meal supplemented with oxytetracycline reported the presence of 107 AR genes conferring resistance to aminoglycosides, vancomycin, macrolide-lincosamide-streptogramin B, tetracyclines, chloramphenicol, and sulfonamides, showing a notable prevalence of tetracycline resistance genes [10]. The genes conferring resistance to tetracycline, including tet $(\mathrm{M})$ and tet $(\mathrm{O})$, were also stably present in the gut of $H$. illucens larvae during bioconversion of manure collected from chickens treated with subtherapeutic doses of tetracyclines [21].

Although these ubiquitous genes could be associated with the H. illucens core microbiota, the higher number of tet $(\mathrm{M})$ and $\operatorname{erm}(\mathrm{B})$ genes detected even in the first round of PCR, as well as the exclusive presence of the erm(A) and aac-aph genes in the larvae reared on the substrates enriched with I. galbana, could indicate a positive correlation between this microalga and the bacteria carrying these genes. The $\operatorname{erm}(\mathrm{A})$ gene is the most common AR determinant in staphylococci, mostly detected in methicillin-resistant strains [44], whereas the aac-aph gene conferring resistance to aminoglycosides has frequently been detected in Gram-positive bacteria mainly belonging to the genera Enterococcus, Staphylococcus, and Streptococcus and rarely in Gram-negative bacteria [45]. Finally, the highest number (6/12) of all tested AR genes was detected in larvae reared on substrates containing $25 \%$ I. galbana (HCsI25).

Since a strong correlation between the H. illucens gut microbiome and resistome has been reported in a study performed by Liu et al. [10], similar associations between the AR genes detected in H. illucens larvae in the present study and their microbiota highlighted by Osimani et al. [38] could be hypothesized. Indeed, Osimani et al. [38] recently reported the prevalence of Paenibacillus in larvae reared on basal Cs substrates, whereas Morganella, followed by Paenibacillus, Lysinibacillus, and Enterococcus, prevailed in H. illucens reared on substrates enriched with I. galbana. Multidrug-resistant species from the Morganella genus that are able to spread AR genes horizontally among the same or different species have been reported by Liu et al. [46]. In contrast, larvae fed substrates containing S. limacinum were characterized by a large prevalence of Brevundimonas, followed by Enterococcus and Paenibacillus. Of note, all of the identified genera include the Firmicutes or Proteobacteria phyla, both commonly associated with multiple resistances [47]. Furthermore, the Proteobacteria is recognized as a potential reservoir of genes conferring resistance to tetracyclines and comprises AR determinants for all important antibiotic resistance mechanisms [48]. Interestingly, the only two studies trying to elucidate the correlation between the microbiota and resistome of $H$. illucens larvae reported contradictory results. Indeed, Liu et al. [10] found a strong correlation between tetracycline resistance genes and Enterococcus, Ignatzschineria, Bordetella, Providencia, and Proteus, whereas the analyses performed by Cai et al. [21] resulted in a very poor correlation between the target AR genes and the relative abundance of genera present in the gut of $H$. illucens larvae.

Little is known about the microbiota of frass collected during the rearing of $\mathrm{H}$. illucens $[22,38,41,49]$, and only two studies investigated the occurrence of AR genes in insect frass collected during the rearing of H. illucens [22] and T. molitor [20] larvae. In the present study, a high contamination level of frass by bacteria carrying the AR genes under study was assumed. Similarly, an accumulation of AR determinants in feed residues collected at the end of the H. illucens rearing process was reported by Cifuentes et al. [22]. In the present study, the accumulation phenomenon was more evident in frass collected from larvae fed substrates enriched with microalgae, thus explaining the results of the cluster analysis and orthogonal contrasts. Furthermore, I. galbana could be associated with the almost exclusive presence of $\operatorname{erm}(\mathrm{C})$ and mecA genes in frass, both typically detected in staphylococci. The $\mathrm{erm}(\mathrm{C})$ gene is commonly responsible for erythromycin resistance in methicillin-susceptible strains [44], whereas mec $A$ confers resistance against methicillin, nafcillin, oxacillin, and cephalosporins [50]. Similarly, Cifuentes et al. [22] reported the high abundance of the latter gene in feed residues without being previously detected in H. illucens gut samples. The 
same authors reported a strong correlation of the mecA gene with the relative abundance of staphylococci. Such a correlation could only be partly assumed in the present study since the metataxonomic analysis performed by Osimani et al. [38] revealed extremely low relative abundances for this group of microorganisms among the same frass samples. Indeed, Brevundimonas, followed by Alcaligenes and Enterococcus, prevailed in the frass from H. illucens fed I. galbana, whereas the predominance of Brevundimonas, followed by Trichococcus and Myroides, was observed in the frass from larvae fed S. limacinum-enriched diets. As discussed above, the identified genera belong to the Firmicutes, Proteobacteria or Bacteroides phyla, all commonly associated with multiple resistances [47,51]. The accumulation of AR genes in frass during the rearing of H. illucens larvae is of great concern since this waste can be used as a biofertilizer [52,53], acting beneficially on plant growth by inducing plant resistance mainly due to the presence of chitosan, a derivative of chitin [54], or more recently, as a fish diet supplement [55], thus posing potential safety risks for the environment and humans.

\section{Conclusions}

Little is still known about the occurrence of AR genes in H. illucens; hence, the results of the present study could represent a valuable contribution to this important safety issue, especially when $H$. illucens larvae are intended to be used as a feed or food ingredient. This study was designed to elucidate the effect of Cs-based rearing substrates supplemented with increasing percentages of S. limacinum or I. galbana microalgae on the occurrence of the selected AR genes in H. illucens larvae and their frass. Different inclusion percentages of microalgae did not significantly influence the distribution of AR genes in H. illucens larvae even if high percentages of I. galbana could be associated with a slightly higher prevalence of the tested AR genes. A significant accumulation of AR genes was observed in the frass, which was more evident for the samples obtained after rearing $H$. illucens larvae on substrates containing high inclusion percentages of I. galbana, thus raising safety concerns about reusing this waste in agriculture. The data obtained represent a first baseline to be used in future AR risk assessment in the edible insect feed chain; until then, prudent use of antibiotics during the rearing of edible insects has been recommended. Further research is needed to better clarify the correlation between the copy number of AR genes carried by the microbial communities occurring in the rearing substrates and those contained in the insect gut and in the resulting frass using quantitative PCR assays.

Supplementary Materials: The following are available online at https:/ / www.mdpi.com/2073-442 5/12/2/213/s1, Figure S1: Representative gel electrophoresis images of PCR (panel A) and nested PCR (panel B) amplification products of 12 target antibiotic resistance (AR) genesscreened in the present study.

Author Contributions: V.M. Investigation, Data curation, Writing—original draft, A.R.; Investigation, Data curation, F.C. (Francesca Clementi); Investigation, C.G., Methodology, Validation, L.A.; Supervision, Validation, P.R.; Conceptualization, Investigation, S.R., Investigation, Validation, L.C.; Investigation, N.I.; Supervision, Resources, M.Z.; Investigation, I.O., Funding acquisition, Project administration, S.C.; Formal analysis, S.T.; Formal analysis, F.C. (Federica Cardinali); Project administration, A.O.; Resources, Data curation, Supervision, Project administration, Writing-review and editing. All authors have read and agreed to the published version of the manuscript.

Funding: This study was funded by Ricerca Scientifica 2017 Cariverona, Italy, NUTRIFISH Project $\mathrm{N}^{\circ}$ 2017.0571.

Institutional Review Board Statement: Not applicable.

Informed Consent Statement: Not applicable.

Acknowledgments: The authors wish to thank Francesco Campostrini at Società Agricola Alghitaly srl, 37066, Sommacampagna, Verona, Italy, for providing the microalgae.

Conflicts of Interest: The authors declare no conflict of interest. 


\section{References}

1. Van Huis, A.; van Itterbeeck, J.; Klunder, H.; Mertens, E.; Halloran, A.; Muir, G.; Vantomme, P. Edible Insects—Future Prospects for Food and Feed Security; Forestry Paper No. 171; Food and Agricultural Organization of the United Nations, FAO: Rome, Italy, 2013.

2. Henry, M.; Gasco, L.; Piccolo, G.; Fountoulaki, E. Review on the use of insects in the diet of farmed fish: Past and future. Anim. Feed Sci. Technol. 2015, 203, 1-22. [CrossRef]

3. Smetana, S.; Palanisamy, M.; Mathys, A.; Heinz, V. Sustainability of insect use for feed and food: Life cycle assessment perspective. J. Clean. Prod. 2016, 137, 741-751. [CrossRef]

4. Van Huis, A.; Oonincx, D.G.A.B. The environmental sustainability of insects as food and feed. A review. Agron. Sustain. Dev. 2017, 37, 43. [CrossRef]

5. Arru, B.; Furesi, R.; Gasco, L.; Madau, F.A.; Pulina, P. The introduction of insect meal into fish diet: The first economic analysis on European sea bass farming. Sustainability 2019, 11, 1697. [CrossRef]

6. European Commission. Commission Regulation (EU) 2017/893 of 24 May 2017 Amending Annexes I and IV to Regulation (EC) No 999/2001 of the European Parliament and of the Council and Annexes X, XIV and XV to Commission Regulation (EU) No 142/2011 as Regards the Provisions on Processed Animal Protein. OJEU 2017, L138, 92-116.

7. Proc, K.; Bulak, P.; Wiącek, D.; Bieganowski, A. Hermetia illucens exhibits bioaccumulative potential for 15 different elementsImplications for feed and food production. Sci. Total Environ. 2020, 723, 138125. [CrossRef]

8. Nguyen, T.T.X.; Tomberlin, J.K.; Vanlaerhoven, S. Influence of resources on Hermetia illucens (Diptera: Stratiomyidae) larval development. J. Med. Entomol. 2013, 50, 898-906. [CrossRef]

9. Truzzi, C.; Giorgini, E.; Annibaldi, A.; Antonucci, M.; Illuminati, S.; Scarponi, G.; Riolo, P.; Isidoro, N.; Conti, C.; Zarantoniello, M.; et al. Fatty acids profile of black soldier fly (Hermetia illucens): Influence of feeding substrate based on coffee-waste silverskin enriched with microalgae. Anim. Feed Sci. Technol. 2020, 259, 114309. [CrossRef]

10. Liu, C.; Yao, H.; Chapman, S.J.; Su, J.; Wang, C. Changes in gut bacterial communities and the incidence of antibiotic resistance genes during degradation of antibiotics by black soldier fly larvae. Environ. Int. 2020, 142, 105834. [CrossRef]

11. Purschke, B.; Scheibelberger, R.; Axmann, S.; Adler, A.; Jäger, H. Impact of substrate contamination with mycotoxins, heavy metals and pesticides on the growth performance and composition of black soldier fly larvae (Hermetia illucens) for use in the feed and food value chain. Food Addit. Contam. 2017, 34, 1410-1420. [CrossRef]

12. Garofalo, C.; Milanović, V.; Cardinali, F.; Aquilanti, L.; Clementi, F.; Osimani, A. Current knowledge on the microbiota of edible insects intended for human consumption: A state-of-the-art review. Food Res. Int. 2019, 125, 108527. [CrossRef] [PubMed]

13. Rice, E.W.; Wang, P.; Smith, A.L.; Stadler, L.B. Determining hosts of antibiotic resistance genes: A review of methodological advances. Environ. Sci. Technol. Lett. 2020, 7, 282-291. [CrossRef]

14. Milanović, V.; Osimani, A.; Pasquini, M.; Aquilanti, L.; Garofalo, C.; Taccari, M.; Cardinali, F.; Riolo, P.; Clementi, F. Getting insight into the prevalence of antibiotic resistance genes in specimens of marketed edible insects. Int. J. Food Microbiol. 2016, 227, 22-28. [CrossRef] [PubMed]

15. Milanović, V.; Osimani, A.; Roncolini, A.; Garofalo, C.; Aquilanti, L.; Pasquini, M.; Tavoletti, S.; Vignaroli, C.; Canonico, L.; Ciani, M.; et al. Investigation of the dominant microbiota in ready-to-eat grasshoppers and mealworms and quantification of carbapenem resistance genes by qPCR. Front. Microbiol. 2018, 9, 3036. [CrossRef]

16. Osimani, A.; Garofalo, C.; Aquilanti, L.; Milanović, V.; Cardinali, F.; Taccari, M.; Pasquini, M.; Tavoletti, S.; Clementi, F. Transferable antibiotic resistances in marketed edible grasshoppers (Locusta migratoria migratorioides). J. Food Sci. 2017, 82, 1184-1192. [CrossRef]

17. Osimani, A.; Cardinali, F.; Aquilanti, L.; Garofalo, C.; Roncolini, A.; Milanović, V.; Pasquini, M.; Tavoletti, S.; Clementi, F. Occurrence of transferable antibiotic resistances in commercialized ready-to-eat mealworms (Tenebrio molitor L.). Int. J. Food Microbiol. 2017, 263, 38-46. [CrossRef]

18. Vandeweyer, D.; Milanović, V.; Garofalo, C.; Osimani, A.; Clementi, F.; van Campenhout, L.; Aquilanti, L. Real-time PCR detection and quantification of selected transferable antibiotic resistance genes in fresh edible insects from Belgium and the Netherlands. Int. J. Food Microbiol. 2019, 290, 288-295. [CrossRef]

19. Roncolini, A.; Cardinali, F.; Aquilanti, L.; Milanović, V.; Garofalo, C.; Sabbatini, R.; Suliman Abaker, M.S.; Pandolfi, M.; Pasquini, M.; Tavoletti, S.; et al. Investigating antibiotic resistance genes in marketed ready-to-eat small crickets (Acheta domesticus). J. Food Sci. 2019, 84, 3222-3232. [CrossRef]

20. Osimani, A.; Milanović, V.; Cardinali, F.; Garofalo, C.; Clementi, F.; Ruschioni, S.; Riolo, P.; Isidoro, N.; Loreto, N.; Galarini, R.; et al. Distribution of transferable antibiotic resistance genes in laboratory-reared edible mealworms (Tenebrio molitor L.). Front. Microbiol. 2018, 9, 2702. [CrossRef]

21. Cai, M.; Ma, S.; Hu, R.; Tomberlin, J.K.; Thomashow, L.S.; Zheng, L.; Li, W.; Yu, Z.; Zhang, J. Rapidly mitigating antibiotic resistant risks in chicken manure by Hermetia illucens bioconversion with intestinal microflora. Environ. Microbiol. 2018, 20, 4051-4062. [CrossRef]

22. Cifuentes, Y.; Glaeser, S.P.; Mvie, J.; Bartz, J.O.; Müller, A.; Gutzeit, H.O.; Vilcinskas, A.; Kampfer, P. The gut and feed residue microbiota changing during the rearing of Hermetia illucens larvae. Antonie Van Leeuwenhoek 2020, 113, 1323-1344. [CrossRef] [PubMed]

23. Van Huis, A. Insect as food and feed, a new emerging agricultural sector: A review. J. Insects Food Feed 2020, 6, 27-44. [CrossRef] 
24. Truzzi, C.; Annibaldi, A.; Girolametti, F.; Giovannini, L.; Riolo, P.; Ruschioni, S.; Olivotto, I.; Illuminati, S. A chemically safe way to produce insect biomass for possible application in feed and food production. Int. J. Environ. Res. Public Health 2020, 17, 2121. [CrossRef]

25. Iriondo-DeHond, A.; Rios, M.B.; Herrera, T.; Rodriguez-Bertos, A.; Nuñez, F.; San Andres, M.I.; Sanchez-Fortun, S.; del Castillo, M.D. Coffee silverskin extract: Nutritional value, safety and effect on key biological functions. Nutrients 2019, 11, 2693. [CrossRef]

26. Aarts, H.; Margolles, A. Antibiotic resistance genes in food and gut (non-pathogenic) bacteria. Bad genes in good bugs. Front. Microbiol. 2015, 5, 754. [CrossRef] [PubMed]

27. Rolain, J.M. Food and human gut as reservoirs of transferable antibiotic resistance encoding genes. Front. Microbiol. 2013, 4, 173. [CrossRef]

28. Martinez, J.L.; Coque, T.M.; Baquero, F. What is a resistance gene? Nat. Rev. Microbiol. 2015, 13, 116-123. [CrossRef]

29. Weisburg, W.G.; Barns, S.M.; Pelletier, D.A.; Lane, D.J. 16 S ribosomal DNA amplification for phylogenetic study. J. Bacteriol. 1991, 173, 697-703. [CrossRef]

30. Milanović, V.; Osimani, A.; Aquilanti, L.; Tavoletti, S.; Garofalo, C.; Polverigiani, S.; Litta-Mulondo, A.; Cocolin, L.; Ferrocino, I.; di Cagno, R.; et al. Occurrence of antibiotic resistance genes in the faecal DNA of healthy omnivores, ovo-lacto vegetarians and vegans. Mol. Nutr. Food Res. 2017, 61, 1601098. [CrossRef]

31. Garofalo, C.; Vignaroli, C.; Zandri, G.; Aquilanti, L.; Bordoni, D.; Osimani, A.; Clementi, F.; Biavasco, F. Direct detection of antibiotic resistance genes in specimens of chicken and pork meat. Int. J. Food Microbiol. 2007, 113, 75-83. [CrossRef]

32. Jacob, A.-E.; Hobbs, S.-J. Conjugal transfer of plasmid borne multiple antibiotic resistance in Streptococcus fecalis var.zymogenes. J. Bacteriol. 1974, 117, 360-372. [CrossRef] [PubMed]

33. Milanović, V.; Aquilanti, L.; Tavoletti, S.; Garofalo, C.; Osimani, A.; de Filippis, F.; Ercolini, D.; Ferrocino, I.; Cagno, R.D.; Turroni, S.; et al. Distribution of antibiotic resistance genes in the saliva of healthy omnivores, ovo-lacto-vegetarians, and vegans. Genes 2020, 11, 1088. [CrossRef] [PubMed]

34. Granados-Chinchilla, F.; Rodríguez, C. Tetracyclines in food and feeding stuffs: From regulation to analytical methods, bacterial resistance, and environmental and health implications. J. Anal. Methods Chem. 2017. [CrossRef] [PubMed]

35. Roberts, M.C.; Schwarz, S. Tetracycline and phenicol resistance genes and mechanisms: Importance for agriculture, the environment, and humans. J. Environ. Qual. 2016, 45, 576-592. [CrossRef] [PubMed]

36. Da Costa, P.M.; Loureiro, L.; Matos, A.J.F. Transfer of multidrug-resistant bacteria between intermingled ecological niches: The interface between humans, animals and the environment. Int. J. Environ. Res. Public Health 2013, 10, 278-294. [CrossRef]

37. Novais, C.; Freitas, A.R.; Silveira, E.; Baquero, F.; Peixe, L.; Roberts, A.P.; Coque, T.M. Different genetic supports for the tet(S) gene in enterococci. Antimicrob. Agents Chemother. 2012, 56, 6014-6018. [CrossRef]

38. Osimani, A.; Ferrocino, I.; Corvaglia, M.R.; Roncolini, A.; Milanović, V.; Garofalo, C.; Aquilanti, L.; Riolo, P.; Ruschioni, S.; Jamshidi, E.; et al. Microbial dynamics in rearing trials of Hermetia illucens larvae fed coffee silverskin and microalgae. Food Res. Int. 2021, 110028. [CrossRef]

39. Ricci, A.; Allende, A.; Bolton, D.; Chemaly, M.; Davies, R.; Girones, R.; Herman, L.; Koutsoumanis, K.; Lindqvist, R.; Nørrung, B.; et al. Scientific opinion on the update of the list of QPS-recommended biological agents intentionally added to food or feed as notified to EFSA. EFSA J. 2017, 15, e04664.

40. Álvarez-Cisneros, Y.M.; Ponce-Alquicira, E. Antibiotic Resistance in Lactic Acid Bacteria; IntechOpen: London, UK, $2018 ;$ pp. 53-73.

41. Bruno, D.; Bonelli, M.; de Filippis, F.; di Lelio, I.; Tettamanti, G.; Casartelli, M.; Ercolini, D.; Caccia, S. The intestinal microbiota of Hermetia illucens larvae is affected by diet and shows a diverse composition in the different midgut regions. Appl. Environ. Microbiol. 2019, 85, e01864-18. [CrossRef]

42. Jeon, H.; Park, S.; Choi, J.; Jeong, G.; Lee, S.-B.; Choi, Y.; Lee, S.-J. The intestinal bacterial community in the food waste-reducing larvae of Hermetia illucens. Curr. Microbiol. 2011, 62, 1390-1399. [CrossRef]

43. Zheng, L.; Crippen, T.L.; Singh, B.; Tarone, A.M.; Dowd, S.; Yu, Z.; Wood, T.K.; Tomberlin, J.K. A survey of bacterial diversity from successive life stages of black soldier fly (Diptera: Stratiomyidae) by using $16 \mathrm{~S}$ rDNA pyrosequencing. J. Med. Entomol. 2013, 50, 647-658. [CrossRef] [PubMed]

44. Lina, G.; Quaglia, A.; Reverdy, M.E.; Leclercq, R.; Vandenesch, F.; Etienne, J. Distribution of genes encoding resistance to macrolides, lincosamides, and streptogramins among staphylococci. Antimicrob. Agents Chemother. 1999, 43, 1062-1066. [CrossRef] [PubMed]

45. Aishwarya, K.V.L.; Geetha, P.V.; Eswaran, S.; Mariappan, S.; Sekar, U. Spectrum of aminoglycoside modifying enzymes in gram-negative bacteria causing human infections. J. Lab. Physicians 2020, 12, 27-31.

46. Liu, H.; Zhu, J.; Hu, Q.; Rao, X. Morganella morganii, a non-negligent opportunistic pathogen. Int. J. Infect. Dis. 2016, 50, 10-17. [CrossRef] [PubMed]

47. Jiang, X.; Ellabaan, M.M.H.; Charusanti, P.; Munck, C.; Blin, K.; Tong, Y.; Weber, T.; Sommer, M.O.A.; Lee, S.Y. Dissemination of antibiotic resistance genes from antibiotic producers to pathogens. Nat. Commun. 2017, 8, 15784. [CrossRef]

48. Walsh, C. Molecular mechanisms that confer antibacterial drug resistance. Nature 2000, 406, 775-781. [CrossRef]

49. Wynants, E.; Frooninckx, L.; Crauwels, S.; Verreth, C.; de Smet, J.; Sandrock, C.; Wohlfahrt, J.; van Schelt, J.; Depraetere, S.; Lievens, B.; et al. Assessing the microbiota of black soldier fly larvae (Hermetia illucens) reared on organic waste streams on four different locations at laboratory and large scale. Microb. Ecol. 2019, 77, 913-930. [CrossRef] 
50. Carretto, E.; Visiello, R.; Nardini, P. Methicillin resistance in Staphylococcus aureus. In Pet-to-Man Travelling Staphylococci: A World in Progress; Savini, V., Ed.; Macmillan Publishers: New York, NY, USA, 2018; pp. 225-235.

51. Wexler, H.M. Bacteroides: The good, the bad, and the nitty-gritty. Clin. Microbiol. Rev. 2007, 20, 593-621. [CrossRef]

52. Halloran, A.; Roos, N.; Eilenberg, J.; Cerutti, A.; Bruun, S. Life cycle assessment of edible insects for food protein: A review. Agron. Sustain. Dev. 2016, 36, 57. [CrossRef]

53. Quilliam, R.S.; Nuku-Adeku, C.; Maquart, P.; Little, D.; Newton, R.; Murray, F. Integrating insect frass biofertilisers into sustainable peri-urban agro-food systems. J. Insects Food Feed 2020, 6, 315-322. [CrossRef]

54. Sharp, G.R. A review of the applications of chitin and its derivatives in agriculture to modify plant-microbial interactions and improve crop yields. Agronomy 2013, 3, 757-793. [CrossRef]

55. Yildirim-Aksoy, M.; Eljack, R.; Schrimsher, C.; Benjamin, H.; Beck, B.H. Use of dietary frass from black soldier fly larvae, Hermetia illucens, in hybrid tilapia (Nile x Mozambique, Oreocromis niloticus x O. mozambique) diets improves growth and resistance to bacterial diseases. Aquac. Rep. 2020, 17, 100373. [CrossRef] 